\title{
II. Heights of some of the principal beds of Ingleborough Hill and Moughton Fell, Yorkshire
}

\author{
John Nixon Esq.
}

To cite this article: John Nixon Esq. (1828) II. Heights of some of the principal beds of Ingleborough Hill and Moughton Fell, Yorkshire, Philosophical Magazine Series 2, 3:13, 11-14, DOI: $10.1080 / 14786442808674533$

To link to this article: http://dx.doi.org/10.1080/14786442808674533

里 Published online: 10 Jul 2009.

Submit your article to this journal $[\pi$

Q View related articles ¿ 


\section{Depression of the Mercury in the Tubes of Barometers.}

\begin{tabular}{|c|c|c|}
\hline $\begin{array}{l}\text { Diameter. } \\
\text { inches. }\end{array}$ & $\begin{array}{l}\text { Depression. } \\
\text { inches }\end{array}$ & $\begin{array}{c}\text { Observed by } \\
\text { Ld. Cavendish }\end{array}$ \\
\hline $0 \cdot 05$ & 0.29490 & \\
\hline$\cdot 10$ & $\cdot 14026$ & 0.140 \\
\hline$\cdot 15$ & $\cdot 08628$ & .092 \\
\hline .20 & $\cdot 05811$ & $\cdot 067$ \\
\hline .25 & .04077 & $\cdot 050$ \\
\hline$\cdot 30$ & .02919 & $\cdot 036$ \\
\hline$\cdot 35$ & .02110 & $\cdot 025$ \\
\hline .40 & $\cdot 01534$ & .015 \\
\hline .45 & $\cdot 01117$ & \\
\hline .50 & $.00815^{*}$ & .007 \\
\hline$\cdot 60$ & $.00431^{*}$ & $\cdot 005$ \\
\hline$\cdot 70$ & $\cdot 00228$ & \\
\hline .80 & .00119 & \\
\hline
\end{tabular}

Dec. 14, 1827.

J. Ivory.

II. Heights of some of the principal Beds of Ingleborough Hill and Moughton Fell, Yorkshire. By John Nixon, Esq.

To the Editors of the Philosophical Magazine and Annals.

Gentlemen,

IN the xith volume of the Annals of Philosophy, I pro-

posed to the geologist the measurement, by one barometer only, of the heights and dip of strata known to be nearly horizontal, and furnished at the same time the requisite instructions and tables. From the numerous measurements of this description made by me in different parts of the northwest of Yorkshire, I beg to transmit you a selection of such as may serve to determine the thicknesses and dip of the principal beds of Ingleborough Hill and Moughton Fell.

Having carefully measured by trigonometry the heights of the summits and other elevated parts of the hills, as well as of different places at their bases, barometrical observations were

* In the Supplement to the Encyclopædia, Article Furros, there is an arithmetical blunder in each of these numbers, as will appear by having recourse to the formula. I was obliged to notice this point on a former occasion, in order to stop the triumph of an antagonist, who has stuck to my skirts for a period of at least six years, and who seems to have great confidence in the efficacy of the adage, If one way will not do, another will. 
regularly made in the course of the day at the lowest and highest of the trigonometrical stations within reach, in order to ascertain and correct the error of the measurements by the barometer. When the station at the base could not conveniently be revisited, the observation at the superior one, together with their difference of altitude, served to determine the fall or rise of the barometer.

The following list, comprising the chief beds of the Ingleton Fells, is arranged conformably to their order of superposition.

A 1. Various beds of grits: Yorkshire paving grits (very siliceous), micaceous sandstones (flagstones and roofing slates) with beds of shale, bearing on some hills three seams of coal.

2. Very rough millstone grit (240 feet thick on Pen-y-gent).

B. The top lime of the Ingleton Fells and the upper part of Wharfdale. It is of very variable thickness, and contains lead in Dod and Settron Fells.

C. 1. A thick bed of various shales with grits and flagstone beds interstratified. It contains a seam of coal on Noughtberry hill at the Garsdale, King's-cross, and pits.

2. Various beds of paving grits, flagstone beds, and shales. In the lower half of this section are two or three very thin beds of limestone.

3. Yorkshire paving grit and shale.

D. 1. Limestone shale containing beds of Dent black marble.

2. Gray limestone without shale, \&c. Lead has been found in this bed south-west of the summit of Ingleborough, and is at present procured on the north-west side of the hill.

3. (In some places) a very thin bed of clayshale containing a slender seam of coal.

E. Grauwacke, (clayslate, \&c.?)

Heights of different points of these scctions, with their bearings and distances from the summil of Ingleborough.

A. 1 \& 2. Height of the station on the loftiest point of Ingleborough, 2374 feet above the Irish Sea.

B. Height of the upper surface of the top lime on the summit of Simon Fell (part of Ingleborough) one mile E.N.E., 2125 feet.

C. 1. Height of the under surface of the top lime (at a spring) half mile E.S.E., 2062 feet; - (at a spring dividing Simon Fell from Ingleborough) half mile E.N.E., 2061 feet;-(on Simon Fell) $1 \frac{1}{4}$ mile E.N.E., 2035 
feet. Height of some quarries of grit slate, $\frac{3}{4}$ mile S., 2090 feet; - (on Simon Fell, east side), $1 \frac{1}{\frac{1}{4}}$ mile E. by N., 1968 feet.

C. 2. Height of the upper surface of a thin (15 to 20 feet) bed

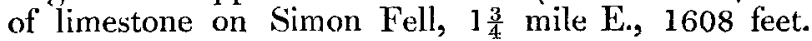
Height of another bed of limestone near the last, 1479 feet.

3. Quarry of thin grit slate, $1 \frac{3}{4}$ mile E., 1427 feet.

D. 1. Height of the upper surface of the Dent marble bed, $1 \frac{1}{2}$ mile S. by W. (in the direction of Newby), 1467 feet; $-1 \frac{1}{2}$ mile S. by E., 1368 feet;-I $\frac{1}{2}$ mile S.S.E., 1395 feet;-(on Simon Fell) $1 \frac{3}{4}$ mile E.S.E., 1350 feet;-(near Selside) 2 miles E., 1270 feet;-(on Park Fell, part of Simon Fell,) $2 \frac{1}{4}$ miles N.E., 1166 feet.

E. Height of the granwacke (in the Ribble under NewInn Bridge near Harton), $4 \frac{1}{4}$ miles E.S.E., 740 feet; (near the blue slate quarries at the south-east end of Moughton Fell) $4 \frac{1}{2}$ miles S.E., 1116 feet. (This is the loftiest point of the denuded grauwacke.) At Hunterstyle (near Cromack) 3 miles S.E., 1047 feet; - under the linge grauwacke boulders near Austwick) $3 \frac{3}{4}$ miles S.S.E., 705 feet;-(in Clapham beck, a patch a little below the recently discovered cave in the limestone, 3 miles S. by E., about 600 feet:-(in the Greta, 3 miles above Ingleton,) $1 \frac{1}{4}$ mile N.W., about 750 feet.

Dip of the beds above the grauroacke.-A comparison of the heights of C. 1. and especially of D. 1. to the south and north of the station on Ingleborough, indicates the dip of these beds to be northerly. Near Newby the height of D. 1. is 1467

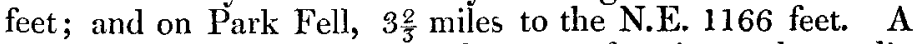
fall of 300 feet in a distance of 19,360 feet is equal to a dip of $0^{\circ} 53^{\prime} 16^{\prime \prime}$; but as the line of maximum depression is probably more to the north, its angular value will exceed $1^{\circ}$.(At the marble quarries east of Dent and N.N.E. of the station, the height of this bed was found to be 1030 feet*.)

Dip of the graurwacke beds.-In the Greta, $80^{\circ}$ N.E.;-at Hunterstyle, and at the south-east end of Moughton Fell, $45^{\circ}$ S. by E.;-on Swartmoor, $80^{\circ}$ northerly.

Thicknesses of the beds.-A. 2, and perhaps a portion of 1 . about 234 feet on Ingleborough.

B. The top lime is about 80 feet thick on Ingleborough and Simon Fell.

* Visually estimated the dip appears to be most rapid to the south of the summits of Ingleborough and Whernside.

C. On 
C. On Ingleborough, Simon Fell, and Park Fell, about 700 feet thick.

D. As the upper surface of the grauwacke, \&c. apparently diversified with hill and dale previous to the deposition of the superincumbent beds, is not a regular plane, the thickness of this section must vary in conformity. In some parts of Wharfdale it is very probably upwards of 1200 feet in thickness.

I have the honour to be, Gentlemen, Your most obedient servant,

Leeds, Dec. 8, 1827.

JoHN NixoN.

III. On the Thermal Waters of the Alps. By R. BaxeweLI, Esq.

To the Editors of the Philosophical Magazine and Annals. Gentlemen,

WHEN we approach a range of lofty mountains, like that of the Pennine Alps, and observe the calcareous strata on the outer part of the range, bent and contorted in various directions; when we further observe beds of limestone and puddingstone alternating and placed in an elevated position, as we advance to the central part of the range; and that the beds of granite in the central part are frequently vertical; we feel assured that their present contorted or vertical position is not the original one. The opinions of geologists have been much divided respecting the cause or causes that have elevated mountains and given a vertical position to beds that once formed the bottom of the ocean. Those who maintain that subterranean heat has expanded and broken the solid crust of the globe, and has raised from vast depths the ancient bed of the ocean, appeal to a cause that is known to exist, and which seems sufficient to explain most of the various appearances which alpine regions present.

In opposition to this theory, it is asserted that there are no remaining vestiges of the action of subterranean fire in the Alps;- - but this I am convinced is erroneous. It is true that from near the source of the Rhone, to the foot of the Little St. Bernard, there does not occur any known rock of a volcanic character, with the doubtful exception of some rocks in the valley of Sass, and in the Valorsine. I have examined various parts of this range on the northern side of the highest mountains in the Alps, along a line of one hundred and twenty miles; and though I could discover no indications of the action of subterranean heat in the rocks themselves, I was greatly surprised to observe, the numerous thermal springs that are abundantly 